\title{
INNOVATION OF THE STUDY COURSE USING PEARSON HIGHER EDUCATION TOOLS
}

\author{
Kateřina Dvoroková, ${ }^{1}$ Lumír Kulhánek²
}

\begin{abstract}
In the Czech Republic, there is historically a wealth of experience with eLearning. In recent years, however, new platforms were developed that have escaped the attention of the academic sphere. The purpose of this article is to evaluate experience with the platform of Pearson Company within the innovation of the course Monetary Theory and Policy at the Faculty of Economics, Technical University of Ostrava. In the Czech Republic, the history of eLearning has been dating since the year 2000. Among the best-known eLearning projects within universities belonged the project "Virtual University" or the online training system WebCT. The most widely used eLearning tools in the Czech Republic today are LMS Moodle, Articulate, Adobe Captivate, eDoceo, etc. Surprisingly eLearning platforms built within the renowned book publisher - e.g., Pearson or Oxford, are less known in the Czech Republic. In this article, we will, therefore, discuss the possibilities that Pearson platform for eLearning offers for universities, and we will conclude with our further experience with its practical use.
\end{abstract}

JEL Classification Numbers: A23, E52; DOI: http://dx.doi.org/10.12955/cbup.v5.991

Keywords: higher education, LMS Moodle, online courses, test generator.

\section{Introduction}

The IEA's international study center TIMSS (the Trends in International Mathematics and Science Study) conducts international comparative assessments of student achievement in mathematics and science. Libich, J. (2014) highlighted their international survey which reveals that the Czech students in comparison with foreign spend fewer hours with experiments, discussions or presentations of their project, however, much more time to listen to the teacher's monologue. The teaching should not be limited to transmitting information, especially in today's era of modern technology where any information is available within seconds. The teacher should be mainly moderator who asks questions and seeks discussion of students in the right direction. Rose \& Goll (1992) demonstrated that after 48 hours on average, students remember only ten percent of what they read, twenty percent of what they hear and 30 percent what they saw. This finding is in contrast to 70 percent of what they discuss with others, 80 percent of what they use in life, and 95 percent of what they tried to teach someone else. Certainly, there are many factors behind that teaching methods are little effective. Worth noticing is the fact that with the development of technology during the teacher's monologue students take their mobile phones, tablets, laptops. Students naturally redirect their attention from the monologue full of what they can learn on the internet easily to something more interesting at that moment. Is there any possibility to link modern technology in teaching with the learning process to make it more efficient, funnier and more attractive for students?

\section{Theoretical Discussion about new Methods of Learning}

Nowadays, in various fields and different industries, we can find the technological development. It facilitates work; make it easier and more efficient, in many instances. The evolution of computer technology supported such development. Nowadays practically, we cannot find a field in which computer technology or components thereof is not used. Technical development is also very familiar with the area of education and training, in which advanced tutorials and technical equipment that facilitates the work of the teacher on its interpretation is applied. Thanks to modern technology, it is possible to engage students in interactive teaching, which may be not only with the spoken word but on cooperation between teacher and student as well. Claims for educational methods increase, which, in turn, not only facilitates teachers' work, but also provides students with an opportunity to learn how to work with new technologies and thus acquire work experience for the future.

The most popular term for alternative ways of teaching using new methods is an eLearning. It is a concept that indicates the method of learning using interactive environment, electronic materials that run through modern computer technology using the worldwide web, which is not always needed. The forms of eLearning are very diverse. On the other hand, understanding the eLearning is quite simple. eLearning is a different kind of education, in which electronic information and communication technologies are used. Most often, it can be a desktop, tablet or mobile phones also connected to the

\footnotetext{
${ }^{1}$ Faculty of Economics, VŠB-Technical University of Ostrava. Czech Republic. katerina.dvorokova@vsb.cz

${ }^{2}$ Faculty of Economics, VŠB - Technical University of Ostrava. Czech Republic. mojmir.kulhanek@vsb.cz
} 
Internet. The student realizes training or testing of knowledge through eLearning software or online application directly on their devices, e.g. computers. The history of eLearning dates back to the early 19 th century, in 1840 Sir Isaac Pitman laid its roots. Since then the first educational tools and software began to emerge. At the end of the 20th century, eLearning has been progressively implemented into schools. Singh, G., \& Hardaker, G. (2014) draw attention to the potential and importance of learning technologies in higher education. They stressed among other things on the reduction of costs to students (McMillin et al., 2010) and the more flexible learning (Haughey, 2006). eLearning may have some disadvantages also. Rymanova et al. (2015) discussed the lack of social contact between a teacher and students; poor understanding of the content; no opportunity to express knowledge in oral form; requirements for computer and Internet access; requirements for strict self-discipline.

\section{Moodle Software Package}

The vast majority of Czech universities use LMS Moodle software package designed mainly to create supporting educational programs for distance learning. Moodle can be freely downloaded from the internet because its license is the GNU General Public License. This is useful for universities because not only they can save much money, but there is no need to pay extras for administration as well. As regards the content, various components added to the Moodle can facilitate work in this system. Currently, there is an interconnection between standard (full-time, face-to-face) teaching and eLearning. Students use Moodle to log on to the topics of seminar papers or to submit the correspondence tasks. On the other hand, teachers can post materials needed for discussion in lessons there.

Veletsianos and Navarrete (2012) conceded that LMS serves as static repositories of content, failing to provide the robust social experience found on platforms that have garnered societal interest and appeal, such as Facebook. Also, our practical experience led to the realization that LMS Moodle is an excellent tool in the classroom, but it became the repository of learning materials without broader use rather.

\section{Innovation of the Subject Monetary Theory and Policy}

The course Monetary Theory and Policy (MTP) focuses on the key areas of contemporary monetary economics and monetary policy. It presents and compares different theories of money demand and money supply, including their implications for various monetary policy strategies, explains the approaches to the influence of money and financial processes on price levels, inflation, product and other macroeconomic variables, including the creation expectations of economic agents. The course analyzes in detail the process of monetary policy, objectives, instruments and transmission mechanisms of monetary policy conducted by the central bank. It serves well as an overview of monetary policy in the Czech Republic and the world, with an emphasis on the trends of the nineties of the $20^{\text {th }}$ century and necessary perspective adaptations.

The subject MTP is part of a master study program Economic Policy and Administration at the Faculty of Economics, Technical University of Ostrava. In the academic year, 2015/2016 it was decided to change the extent of teaching, which was increased by introducing seminars. Given the current trends in education, the innovation of the subject aims to promote modern teaching methods to lectures and seminars. Its objective is the update of present lectures to reflect the evolution of contemporary monetary theory and practice of monetary policy, and updating the content of special seminars after evaluating experience with the introduction of this form of teaching. According to the absence of electronic support for this study course, we will make the study materials for seminars as well. The innovation of the subject will enable students more in-depth understanding of the topics covered. Contents of the subjects, materials, and tools used in teaching will focus more on practicing set themes so that passing the course at the master's level significantly increases the level of financial literacy in both professional and personal level of the graduates of the course. Benefits of course innovation are to support progressive forms and new methods of education. New materials enable a better understanding of the studied problem based on applied practicing of the subject matter. 


\section{Pearson Higher Education - possibilities and practical use of the study course}

One of the world's companies offering services in the field of education is Pearson PLC. Samuel Pearson founded the company in 1844. The companies headquarter placed in London (United Kingdom of Great Britain and Northern Ireland). Besides services in the field of education, the company aims at businesses in strategic business information, international television production, and consumer publishing. Pearson as a learning company specializes in educational courseware and assessment, and a range of teaching and learning services powered by technology. With 35,000 employees across 70 countries, the company can rightly be considered as a transnational corporation. One of the company's slogans perfectly captures this fact:

"Whether it is through new digital learning products in the US, developing qualifications and Assessments in the UK, training school leaders in the Middle East, teaching English in China, or Educating professionals, we are helping people make progress in their lives through learning," (Who We Are, 2017).

The company in the field of education for the higher education sector offers many products and services. These include Course development, Customisable resources, and technology, MyLab \& Mastering, Online program management, Printed textbooks and eBooks, Learning Catalytics, Simulations, etc. Educators can browse by discipline the catalog on the website https://uk.pearson.com/higher-education-educators.html as well and choose the required scientific discipline.

\section{Course Management with Textbook}

Without the need to register Pearson offers for their own published books supporting resources. For the requirements of our subject, we select Economics, Money, and Banking, MTP. Through such exactly predefined task, each teacher can choose from the list of books published by the company, and for each of them he can use such tools, the company offers for the book. In the case of the subject MTP, we work with the book The Economics of Money, Banking and Financial Markets with MyEconLab, Global Edition, 11/E by Frederic S. Mishkin, Columbia University. On the website, http://catalogue.pearsoned.co.uk/educator/product/The-Economics-of-Money-Banking-and-FinancialMarkets-with-MyEconLab-Global-Edition/9781292094304.page downloadable resources and other resources are available.

Downloadable instructor resources are as follows:

- Instructor's Resource Manual;

- PowerPoint Presentation - contains lecture notes and all the textbook's figures and tables;

- TestGen Computerized Test Bank - contains over 2,500 multiple-choice questions that are appropriate for use as a quiz or test questions. These forms provide us alternative methods to make up exams. The Pearson TestGen program offers us a computerized test generator that lets us construct tests by choosing questions from the Test Bank that was prepared specifically for this textbook. The Test Bank includes four types of questions: multiple choice, true/false, short answer, and essay.

Other resources are as follows:

- Companion Website including web chapters and appendices in PDF format.

In the book itself at the end of each chapter, End-of-Chapter Problems (Questions, Applied Problems, and Web Exercises) are placed. Some of these questions require students to look up current data. We use them mainly for homework assignments.

\section{Course Management with MyEconLab}

Within the innovation of the study course MTP, we use MyLab \& Mastering at most. The tool consists of online homework, tutorial and assessment products such as Learning Catalytics; Adaptive Learning; Econ Experiments; Assign real-time data analysis exercises that use real-time data; Multimedia assets assist students' learning. MyLab courses are available on mobile devices as well, and there is a possibility to integrate them into LMS. Those instruments can only be used to paying the license fee. Without having to pay, Pearson offers an option for instructors to register into the system and enroll in an existing course related to some of the Pearson's published books. 
MyLab \& Mastering has adapted to the needs of the individual disciplines also. We can find support for anatomy and physiology, biology and microbiology, mathematics, etc. For economics, the platform MyEconLab serves. Unlike the service Learning Catalytics, it is possible to use this product partially without paying a license fee.

MyEconLab delivers online content and innovative learning tools to our classroom. To use the basic tools of MyEconLab, it was required to register first. After validation of the instructors by Pearson, we got access to existing courses. If the school had paid for the licenses, then each teacher can create his/her course with particular content. Since the Faculty of Economics does not offer such possibility, we took the approach without a license. In this case, we searched for the already existing course by Frederic S. Mishkin, formed to his book The Economics of Money, Banking, and Financial Markets Global Edition. (2017). Following the enrollment in the course instructor can use particular resources, which include supporting materials for lectures and seminars of all kinds. It is possible to customize the existing content and add our own as well. We can manage, create, and assign tests to students, choosing from the exercises in the Study Plan as well as from the Test Banks.

We considered Chapter Resources to be the most valuable. For each chapter in the book materials of different media types were created:

- Animation;

- Appendix;

- online Textbook;

- Reading - Pearson publishes an annual Readings book online, aimed to enhance the text. The Readings collection is unique in that it is updated over the life of current edition of the textbook. More than that, it includes summaries of the articles, provides suggestions for which textbook chapter(s) the reading might be assigned, and contains discussion questions that follow each reading to encourage students to think about how the reading relates to material in the text;

- Study Guide - includes Chapter Review to summarize the chapter, Helpful Hints to provide additional examples, Terms and Definitions to match key terms to their definitions, Problems and Short-Answer Questions, Critical Thinking to provide a single multi-step problem as an application of the major issue, Self-Test to provide true/false and multiple-choice questions, Solutions to provide solutions for all problems and questions;

- Video;

- web Chapter;

- web Links.

Students and MyEconLab

MyEconLab delivers students access to a variety of study and practice tools that put them in control of their learning. Students can use practice tests to check their understanding and identify areas in which they need to do further work. For each student, a personalized study plan is based on test results will show students where further study is required. Students can choose from many interactive exercises based on specific end-of-chapter questions and select from Readings in Money, Banking, and Financial Markets, regularly updated by Frederic S. Mishkin and James W. Eaton of Bridgewater College. Sample quizzes are also available to give students a chance to double-check their understanding and application of the main topics in each test chapter.

\section{Learning Catalytics}

In the context of products and services listed above, probably the most interesting of them seems to be Learning Catalytics. We believe that this instrument can grab the attention of students during classroom instruction and connect the latest technology while teaching at the same time. Learning Catalytics was founded by Gary King, Brian Lukoff, and Eric Mazur, of Harvard University. It is an advanced, cloud-based learning analytics and assessment response system that helps instructors evaluate student understanding in real-time. It is one of the most interesting tools to attract student's attention known as "bring your own device" student engagement and classroom intelligence system. Thanks to it, the teacher can engage students in real time, using open-ended tasks to probe student understanding, see Figure 1. Students can use any smart web-enabled device they already have laptop, smartphone, or tablet. The teacher creates open-ended questions that ask for a broad range of 
responses. Question types include word clouds, graphing, short answer, matching, multiple choice, highlighting, image upload, etc.

Utilization of this tool is a chargeable service. The license price depends on the length of the period and the number of students with access to the system. Although we could find a use for it (for example, to solve arithmetic problems), this tool has not been used within the innovation of the study course MTP, therefore.

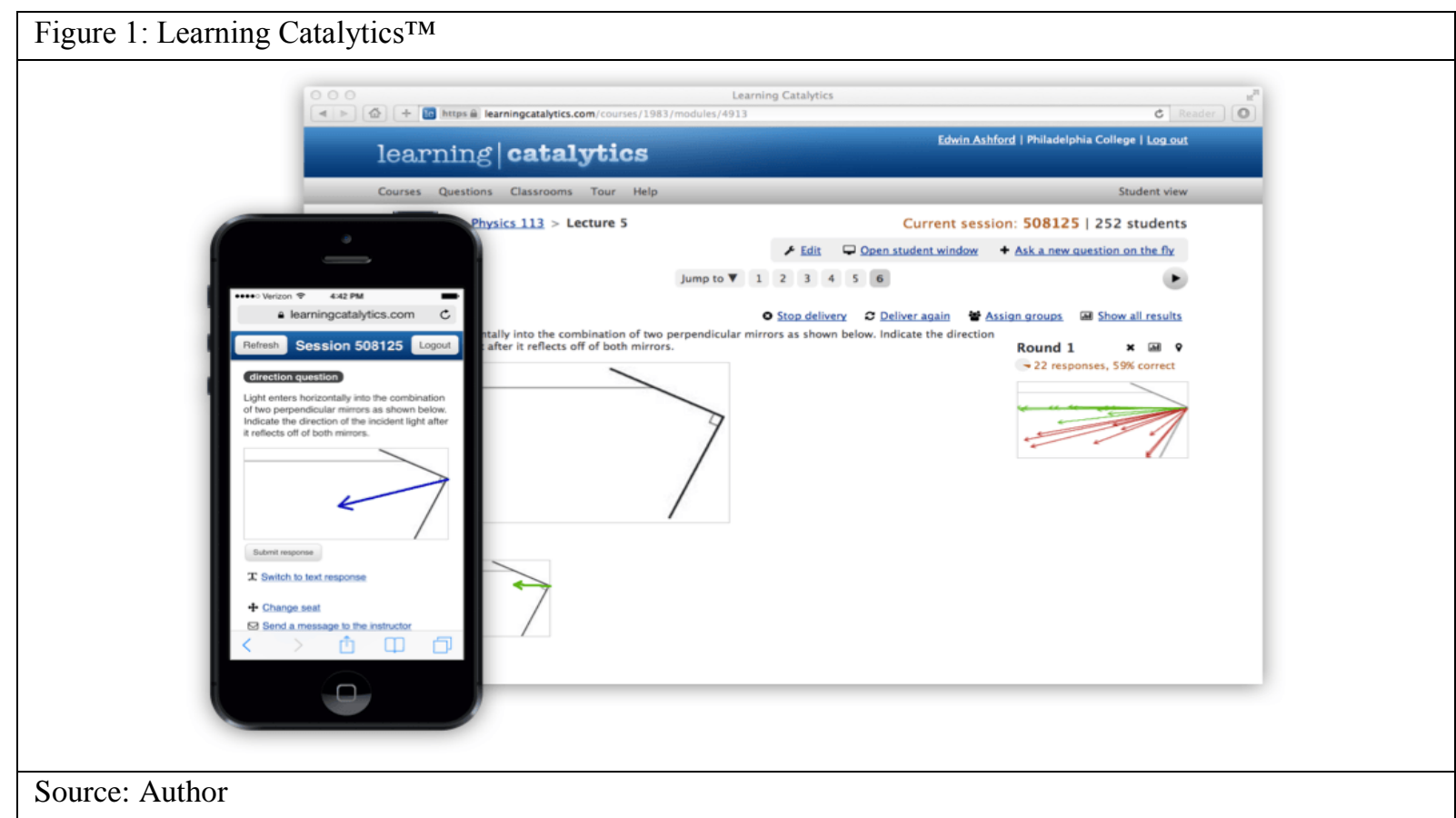

\section{Conclusion}

The innovation of MTP course was motivated by an effort to modernize teaching using current methods and tools in education. Presently, there are several platforms for eLearning available at the market learning tools. At Czech universities, the most used are probably LMS Moodle. Although it brings much innovation to modern education, its major disadvantage is that it places high time and technical demands on instructors. At present, the pressure on teachers to engage in research and publish professional publications is enormous. It remains, therefore, a lack of time to focus on the quality of teaching process. Thus, we consider beneficial to take advantage of opportunities that are offered by professional companies. Pearson PLC is such firm that has for years devoted to the field of education. During the course innovation, we have seen only a fraction of the tools that Pearson offers nevertheless we can say that all of them are handled professionally about the reflection of modern methods in teaching. Therefore, it is worth for Czech universities to consider professional service firms to be more applied in higher education.

\section{Acknowledgements}

The innovation of the study course Monetary Theory and Policy and presentation of this paper is supported by so-called Institutional development projects FRVŠ 2017 (Institucionální rozvojové projekty FRVŠ 2017), the number of the project is RPP/2017/171, and the project is implemented at VŠB-Technical University of Ostrava, Faculty of Economics.

\section{References}

Haughey, M. (2006). Commentary on e-learning in Canada. Canadian Journal of Learning and Technology, Vol. 32 No. 3 , pp. 101-109.

Learning Catalytics. (2016). Retrieved from https://www.pearsonhighered.com/products-and-services/course-content-anddigital-resources/learning-applications/learning-catalytics.html

Libich, J. (2014). Zabíjí škola touhu po vzdělání? Česká Pozice. Retrieved from http://ceskapozice.lidovky.cz/zabiji-skolatouhu-po-vzdelani-dzr-/tema.aspx?c=A140808_170423_pozice-tema_lube

McMillin, V., Ortegies-Young, T. S., \& Kem, L. (2010), Faculty advisor assessment and reward: a hot topic for our institutions. Academic Advising Today, Vol. 33 No. 2. 
Rymanova, I., Baryshnikov, N., \& Grishaeva, A. (2015). E-course Based on the LMS Moodle for English Language Teaching: Development and Implementation of Results: Development and Implementation of Results. Procedia - Social and Behavioral Sciences, 206, 236-240.

Rose, C., \& Goll, L. (1992). Accelerate Your Learning: A World of Opportunity in Your Hands. UK: Accelerated Learning Systems.

Singh, G., \& Hardaker, G. (2014). Barriers and enablers to adoption and diffusion of e-learning. Education \& Training, 56(2), 105-121.

The Economics of Money, Banking and Financial Markets Global Edition. (2017). Retrieved from http://catalogue.pearsoned.co.uk/educator/product/The-Economics-of-Money-Banking-and-Financial-Markets-GlobalEdition/9780273765738.page\#downlaoddiv

Veletsianos, G. and Navarrete, C. C. (2012). Online Social Networks as Formal Learning Environments: Learner Experiences and Activities. The International Review of Research in Open and Distance Learning, 13(1), 144-166.

Who We Are. (2017). Retrieved from https://www.pearson.com/about-pearson/who-we-are.html 